\title{
Turn over Intention among Nurses: The Role of Job Demand and Job Burnout
}

\author{
Praptini Yulianti \\ Department of Management, Faculty of Economic \& Business, Universitas Airlangga, INDONESIA \\ *E-mail for correspondence: praptini-y@feb.unair.ac.id
}

https://doi.org/10.18034/abr.v10i1.463

\begin{abstract}
This study aims to prove the influence of job demand on job burnout and turn over intention. The sample of this study is 96 nurses on hospital private sector in Surabaya, Indonesia. The sampling method uses simple random sampling with online systems. This study examines 3 hypotheses with smart PLS. The result of this study is to prove that job demand has a positive influence on job burnout, job burnout has a positive influence to turn over intention and job demand has a positive influence to turn over intention. Practical Implications states that nurses are vulnerable to job burnout.
\end{abstract}

Key words: Job demand, job burnout, turn over intention

\section{INTRODUCTION}

The nursing profession has risks with a high level of job stress and burnout (Xie et al., 2011). Burnout is a psychological syndrome from emotional burnout, depersonalization, and less self-achievement which occurred between the individual and their coworkers in some capacity (Montgomery et al., 2015). Nurses are vulnerable to burnout because of their job have much pressure and emotional demands, such as routine to get in touch with patients about their needs, problems, and sickness (Bakker et al., 2000). Job demand relates to the physical, social aspects, or organizations from the job that need continuously some physical or mental efforts (Demerouti et al., 2001).

The high level of job demand such as too often demanding over patient and family, serving too many patients at the same time can cause nurses to burnout. Nurses who experience job burnout will feel emotional exhaustion, easier to fatigue at work, impersonal with a patient, and not provide good service. Burnout relates to reducing nurses' productivity, absenteeism, turnover, working unsatisfied, physically, and mentally ill (Maslach \& Jackson, 1981). Demerouti et al., 2001, states that the turnover numbers on nurses in the hospital are the highest turnover of workers than any other technical ability implemented. The turnover intention on nurses is not separate from job demand which becomes some issues to a psychological stressor. The objectives of this study are to prove that job demand will influence job burnout and nurses turn over intention.

\section{LITERATURE REVIEW}

\section{The Relationship of Job Demand and Job Burnout}

Job demands on nurses (such as irregular workhours, time pressure, attending too many patients at the same time, demanding interactions with patients) can cause burnout (Hansen, Sverke, Na"swall, 2009). Each job has different job demands, but basically, the job demand is the energetic role of demanding the job relates to physically or psychologically risky. The first burnout aspects are emotional exhaustion, signed by a disclaimer in doing jobs, having pressures attending too many jobs, and gives up easily (Maslach \& Jackson, 1981). The second burnout aspect depersonalization, signed by a cynical attitude, keeps the distance from the work environment and tend not to be involved in problems about the work environment. The third burnout aspects are low personal accomplishment, signed by some arguments that the nurses are not competent, effective (Wright \& Cropanzano, 1998) and satisfied with their achievements (Maslach et al 1997). Job demand has a positive relationship with burnout (Bon \& Shire, 2017). The following hypothesis was to propose,

$\mathrm{H}_{1}$ : Job demand has a positive influence on job burnout 


\section{The Relationship Job Burnout and Turn over Intention}

Burnout relates to reducing work satisfaction, organization commitment, and increasing turnover intention (Boamah and Laschinger, 2015). Emotional exhaustion has been identified as the main factor causing burnout (Yulianti and Nur, 2018) and increasing turn over intention (Boamah and Laschinger, 2015). Emotion exhaustion on nurses causes disclaimer in doing jobs by acting like keep the distance from the work environment and tend not to be involved in problems about the work environment, in the end, they are not competent. Nurses having some burnout will want to turn over intention. The following hypothesis was to propose,

$\mathrm{H}_{2}$ : Job Burnout has positive influence to turn over intention

\section{The Relationship Job Demand and Turn over intention}

Job demand can give some pressure that the attending tasks which are given are too many so that increasing turnover intention (Peter et al., 2013). The high level of job demand needs more energy in doing tasks that resulted in loses spirit, less energetic on nurses. Nurses with a high level of job demand will reduce their want to invest their effort in doing tasks and not showing their skills when they have some problems. (Abelson, 1987) states burnout on job demand available when the nurses working often make the nurses becoming burdened with their jobs, so it affected them leaving the hospital. Job demand can increase turnover intention (Schaufeli and Bakker, 2004).

The following hypothesis was to propose,

$\mathrm{H}_{3}$ : Job demand has positive influence to turn over intention

\section{Conceptual Frameworks}

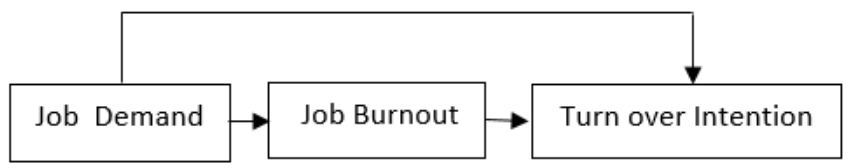

\section{ReseARCH Method}

This study is quantitative. The sample of this study is 96 nurses work on hospital private sector in Surabaya, Indonesia. Questionnaires spread through hospital mailing system on 103 nurses. Participation was voluntary and responses were confidential. The respondent level is $93 \%$. Demographic respondent data is mainly women $(86 \%)$, full-time employees (97\%), ages between 25-30 years old $(72 \%)$, and working period 5 until 10 years $(68 \%)$.

\section{Measurement}

All the constructs measured nurses' perceptions using a five-point Likert scale ranging from 1 (strongly disagree) to 5 (strongly agree). Job demand was measured using four items scale (nurses have over workloads, have limited time to finish the job, feel that the patient over- demanding, and serve too many patients at the same time) by Montgomery et al., 2015. Job burnout measured by 3 dimensions. Emotional Exhaustion, using four items scale (nurses feel emotional exhaustion at work, feel fatigued, frustration, and work too hard). Depersonalization, using four items scale (nurses treat some patient that they seem not important, become impersonal, not so care what happen among patient, feel that some patient condemn them about the problem they faced). Low personal accomplishment, using the four-item scale (nurses don't understand what patients feel, not effectively solve the patient problems, feel uncomfortable at work, worried in handle the emotional problems at work) by Maslach \& Jackson, 1981. Turn over Intention measured by three items (have a plan in a short time to leave, sometimes think to leave, plan to new job alternatives) was developed by Lum et al. (1998).

The analytical technique uses PLS. The analysis and interpretation of a PLS model require two stages: (a) the evaluation of the levels of reliability, convergent and discriminant validity of the measurement model; and (b) the estimation of the structural model. The measurement model is an outer model test to test the validity and reliability construct of this study. See on Table 1, all indicator has loading factor values $>0,5$ and (AVE) is above 0,5. Composite reliability $>0.7$. (Hair et al., 2010). Table 2. Cross loading value on variable has a greater amount than any other variable, so discriminant validity are met. The structural model is the inner model test to test the relationship variable (see, Table 3 ).

Table 1: Evaluation of the measurement model

\begin{tabular}{|c|c|c|c|c|}
\hline Indicator & $\begin{array}{c}\text { Factor } \\
\text { Loadings }\end{array}$ & $\begin{array}{l}\text { Composite } \\
\text { Reliability }\end{array}$ & AVE & Alpha \\
\hline \multicolumn{5}{|l|}{ Job Demand } \\
\hline $\mathrm{JD}_{1}$ & 0.953 & 0.911 & 0.632 & 0.883 \\
\hline $\mathrm{JD}_{2}$ & 0.944 & & & \\
\hline $\mathrm{JD}_{3}$ & 0.960 & & & \\
\hline $\mathrm{JD}_{4}$ & 0.961 & & & \\
\hline \multicolumn{5}{|l|}{ Burnout } \\
\hline BURN01 & 0.874 & 0.986 & 0.923 & 0.983 \\
\hline BURN02 & 0.850 & & & \\
\hline BURN03 & 0.859 & & & \\
\hline BURN04 & 0.897 & & & \\
\hline BURN05 & 0.874 & & & \\
\hline BURN06 & 0.808 & & & \\
\hline BURN07 & 0.720 & & & \\
\hline BURN08 & 0.832 & & & \\
\hline BURN09 & 0.721 & & & \\
\hline BURN10 & 0.835 & & & \\
\hline BURN11 & 0.832 & & & \\
\hline BURN12 & 0.848 & & & \\
\hline \multicolumn{5}{|c|}{ Turn over intention } \\
\hline $\mathrm{TI}_{1}$ & 0.911 & 0.981 & 0.697 & 0.979 \\
\hline $\mathrm{TI}_{2}$ & 0.902 & & & \\
\hline $\mathrm{TI}_{3}$ & 0.926 & & & \\
\hline
\end{tabular}


Table 2: Cross Loading

\begin{tabular}{|c|c|c|c|}
\hline & JD & Burnout & Turn over Intention \\
\hline JD $_{1}$ & 0.976 & 0.231 & 0.725 \\
\hline JD $_{2}$ & 0.962 & 0.308 & 0.765 \\
\hline JD $_{3}$ & 0.952 & 0.347 & 0.803 \\
\hline JD $_{4}$ & 0.980 & 0.246 & 0.746 \\
\hline BURN01 & 0.296 & 0.874 & 0.700 \\
\hline BURN02 & 0.325 & 0.850 & 0.735 \\
\hline BURN03 & 0.129 & 0.859 & 0.755 \\
\hline BURN04 & 0.264 & 0.897 & 0.689 \\
\hline BURN05 & 0.282 & 0.874 & 0.639 \\
\hline BURN06 & 0.243 & 0.808 & 0.599 \\
\hline BURN07 & 0.285 & 0.720 & 0.478 \\
\hline BURN08 & 0.479 & 0.832 & 0.630 \\
\hline BURN09 & 0.210 & 0.721 & 0.550 \\
\hline BURN10 & 0.372 & 0.835 & 0.616 \\
\hline BURN11 & 0.434 & 0.832 & 0.562 \\
\hline BURN12 $_{2}$ & 0.419 & 0.848 & 0.549 \\
\hline TI $_{1}$ & 0.351 & 0.347 & 0.953 \\
\hline TI $_{2}$ & 0.295 & 0.319 & 0.944 \\
\hline TI $_{3}$ & 0.399 & 0.285 & 0.960 \\
\hline
\end{tabular}

Table 3: Path coeficient and Parameter coeficient

\begin{tabular}{|c|c|c|c|c|}
\hline & & $\begin{array}{c}\text { Original } \\
\text { Sample }\end{array}$ & T-Statistics & Remarks \\
\hline $\mathrm{H}_{1}$ & $\begin{array}{c}\text { Job Demand } \\
\text { - Job Burnout }\end{array}$ & 0,404 & 3,846 & Significant \\
\hline $\mathrm{H}_{2}$ & $\begin{array}{c}\text { Burnout - Turn } \\
\text { over Intention }\end{array}$ & 0,256 & 2,418 & Significant \\
\hline $\mathrm{H}_{3}$ & $\begin{array}{c}\text { Job Demand- } \\
\text { Turn over Intention }\end{array}$ & 0,128 & 2,564 & Significant \\
\hline
\end{tabular}

\section{Discussion}

$\mathrm{H}_{1}$ supported, job demand has a positive influence on job burnout. Nurses who feel that serving too many patients at the same time, too often demanding over patient and family can cause them to emotional exhaustion, resulted in impersonal nurses and ineffective on providing good services among patients. $\mathrm{H}_{2}$ supported, Job burnout has a positive influence to turn over intention. Job burnout who is experienced by nurses often provides a motive to leave the organizations and move to another profession. $\mathrm{H}_{3}$ supported, Job demand has a positive influence to turn over intention. The high level of job demand often makes nurses leaving the organization. All hypothesis is supported. Job demand has a bigger contribution to burnout than job demand on influence turn over. Burnout on nurses is faster to increase turn over intention than job demand. This study relates to Schaufeli and Bakker (2004) state that job demand will be faster the burnout process on nurses. Nursing is a profession with high emotional and physical demands because requires face-to-face contact with patients and their families, and nurses must constantly address suffering, pain, and death patients. Therefore, nursing has been considered as a risk profession for burnout. Health professionals, especially nurses, experience high levels of stress, anxiety, emotional overload, and/or compassion fatigue, mainly as a result of the nature of their work and workplace (Yulianti and Nur, 2018). Job demand which demands some emotions causes nurses easier to have emotional exhaustion so they are vulnerable to job burnout.

\section{IMPLICATION}

The practical implication states that the nursing job is vulnerable to have burnout. Job demand for nurses can cause emotional-energetic, the continuous interaction with patients will make nurses vulnerable to emotional exhaustion. Emotional exhaustion as the main factor causing burnout has been many analyzed (Maslach et al., 1997). However, the fact that exhaustion is a necessary criterion for burnout does not mean it is sufficient. Although exhaustion reflects the stress dimension of burnout, it fails to capture the critical aspects of the relationship people have with their work such as depersonalization and low personal accomplishment. The nursing profession needs an emotional demand to provide better service quality to the patients. Nurses who are having depersonalization will keep the distance with their patients by doing not care on give services on patients. This condition causes some difficulty to gain a sense of accomplishment.

\section{CONCLUSION}

Job burnout on nurses can influence them leaving their profession as a nurse. Job demand for nurses gives positive influence and a bigger contribution to burnout. Job burnout on nurses also gives positive influence, such as want to leave their nursing profession. Burnout occurred because of emotional exhaustion, depersonalization dan low personal accomplishment.

\section{REFERENCES}

Abelson, M. A. 1987. Examination of Avoidable and Unavoidable Turnover. Journal of Applied Psychology, 72, 382-386.

Bakker, A. B., Killmer, C. H., Siegrist, J., and Schaufeli, W. B. (2000). Effort reward imbalance and burnout among nurses. Journal of Advanced Nursing, 2000, 31(4), 884-891.

Boamah S.A. and Laschinger H. (2015). The influence of areas of work-life fit and work-life interference on burnout and turnover intentions among new graduate nurses. Journal of Nursing Management

Bon, A. T., \& Shire, A. M. (2017). Job demands, Job Resources, and Affective Commitment. International Journal of Scientific and Research Publications, Volume 7, Issue 1, January 2017. 366372

Demerouti, E., Bakker, A. B., Nachreiner, F., \& Schaufeli, W. B. (2001). The Job Demands- Resources Model of Burnout. Journal of Applied Psychology 2001, Vol 86. No. 3 , 499-512. 
Hair, J.F.; Black, W.C.; Babin, B.J. and Anderson, R.E. (2010) Multivariate Data Analysis, 7th Edition, Pearson, https://www.pearson.com/us/highereducation/program/Hair-Multivariate-Data-Analysis-7thEdition/PGM263675.html

Hansen, N., Sverke, M., \& Näswall, K. (2009). Predicting nurse burnout from demands and resources in three acute care hospitals under different forms of ownership: A crosssectional questionnaire survey. International Journal of Nursing Studies $46 \quad$ (2009) 96-107. https://doi.org/10.1016/j.ijnurstu.2008.08.002

Lum, L., Kervin, J., Clark, K., 1998. Explaining nursing turnover intent: job satisfaction, pay satisfaction, or organizational commitment? Journal of Organizational Behavior, Vol.19, pp 305-320.

Maslach, C., \& Jackson, S. E. (1981). The measurement of experienced burnout. Journal of Occupational Behaviour, 2(2), 99-113. https://doi.org/10.1002/job.4030020205

Maslach, C., Jackson, S. E., \& Leiter, M. (1997). The Maslach Burnout Inventory Manual. Third Edition. Maslach Burnout Inventory
Montgomery, A., Spânu, F., Bəban, A., \& Panagopoulou, E. (2015). Job demands, burnout, and engagement among nurses: A multi-level analysis of ORCAB data investigating the moderating effect of teamwork. Burnout Research, 2(2-3), 71-79. https://doi.org/10.1016/j.burn.2015.06.001

Schaufeli, W. B., \& Bakker, A. B. (2004). Job demands, job resources, and their relationship with burnout and engagement: a multi-sample study. Journal of Organizational Behavior J. Organiz. Behav. 25, 293-315

Wright, T. A., \&Cropanzano, R. (1998). Emotional exhaustion as a predictor of job performance and voluntary turnover. Journal of Applied Psychology, 83(3), 486-493. https:/ / doi.org/10.1037/0021-9010.83.3.486

Xie, Z., Wang, A., \& Chen, B. (2011). Nurse burnout and its association with occupational stress in a cross-sectional study in Shanghai. Journal of Advanced Nursing, 67(7), 15371546. https://doi.org/10.1111/j.1365-2648.2010.05576.x

Yulianti, P. and Nur, N.M., 2018. Antecedent Burnout: Emotional Job Demand, Emotional Display Rules, Emotional Dissonance, International Conference of Organizational Innovation, Volume 2018

$--0--$

Online Archive: https://abc.us.org/ojs/index.php/abr/issue/archive 